Brazilian Journal

of Chemical

Engineering

\title{
ANTIBACTERIAL ACTIVITY OF ZINC OXIDE NANOPARTICLES SYNTHESIZED BY SOLOCHEMICAL PROCESS
}

\author{
Roberta C. de Souza ${ }^{1}$, Leticia U. Haberbeck ${ }^{2}$, Humberto G. Riella ${ }^{1}$, \\ Deise H. B. Ribeiro ${ }^{3}$ and Bruno A. M. Carciofi ${ }^{1 *}$ \\ ${ }^{1}$ Universidade Federal de Santa Catarina, Centro Tecnológico, Departamento de Engenharia Química e Engenharia de Alimentos, \\ Florianópolis, SC, Brasil. ORCID: 0000-0002-3512-9459; ORCID: 0000-0003-0435-6082; \\ E-mail: bruno.carciofi@ufsc.br - ORCID: 0000-0002-9233-0984 \\ ${ }^{2}$ Technical University of Denmark, National Food Institute, Kongens Lyngby - Copenhagen, Denmark. ORCID: 0000-0001-8270-3727 \\ ${ }^{3}$ Universidade Federal de Santa Catarina, Centro de Ciências Agrárias, Departamento de Ciência e Tecnologia de Alimentos, \\ Florianópolis, SC, Brasil. ORCID: 0000-0001-6023-9812
}

(Submitted: January 19, 2018 ; Revised: May 22, 2018 ; Accepted: September 23, 2018)

\begin{abstract}
ZnO-NPs can be obtained through various methods, resulting in nanoparticles with different size and morphology, which directly influences their antimicrobial potential. The objective of this work was to evaluate the antibacterial activity of ZnO-NPs obtained by a solochemical process against important human foodborne pathogens: Staphylococcus aureus, Salmonella Typhimurium, Bacillus cereus and Pseudomonas aeruginosa. $\mathrm{ZnO}-\mathrm{NPs}$ were identified as nanorods with the length between 90.1 and $100 \mathrm{~nm}$ (10.5\% frequency), the diameter between 80.1 and $90 \mathrm{~nm}$ (21\% frequency), and wurtzite type crystalline structure. The Minimum Inhibitory Concentration (MIC) and Minimum Bactericidal Concentration (MBC) were equal to $0.05 \mathrm{mg} \mathrm{mL}^{-1} \mathrm{and} 0.5 \mathrm{mg}$ $\mathrm{mL}^{-1}$ for $S$. aureus and $S$. Typhimurium, respectively, lower than previous results related in the literature. $\mathrm{ZnO}-$ NPs produced by solochemical method had a superior antibacterial activity. For instance, they can be incorporated in packaging materials for increasing microbial safety and food shelf-life by inhibiting bacterial growth.

Keywords: Foodborne pathogens; Bacillus cereus; Staphylococcus aureus; Salmonella Typhimurium; Pseudomonas aeruginosa.
\end{abstract}

\section{INTRODUCTION}

The increasing concern about resistant microorganisms stimulates the study of new and more effective antimicrobial agents (Raghunath and Perumal, 2017; Tang and Lv, 2014). New agents can be obtained from biological sources, such as bacteriocins and essential oils, or synthesized organic/inorganic compounds (Han, 2005; Medeiros et al., 2017; Medeiros et al., 2018). Good antimicrobial effects have been obtained from metal oxide nanoparticles (Raghunath and Perumal, 2017), such as $\mathrm{MgO}$ (Tang et al., 2012), $\mathrm{Cu}_{2} \mathrm{O}, \mathrm{CuO}, \mathrm{ZnO}, \mathrm{TiO}_{2}$, and $\mathrm{WO}_{3}$ (Duffy et al., 2018; Vargas-Reus et al., 2012), which present distinct behavior and properties from micrometric or millimetric particles (Azeredo, 2013; MartinezGutierrez et al., 2010; Morais and Durán, 2006).

Zinc oxide nanoparticles (ZnO-NPs) have been reported as an antimicrobial agent against both pathogenic and spoilage microorganisms (Ann et al., 2014; Duffy et al., 2018; Pasquet et al., 2014; Raghunath and Perumal, 2017; Raghupathi et al., 2011; Savi et al., 2013; Vargas-Reus et al., 2012; Xie et al., 2011). ZnONPs application as antimicrobial agent stands out in comparison to other metallic nanoparticles (Jones et al., 2008). Their main antimicrobial mechanisms have been attributed to the induction of oxidative stress due to the formation of reactive oxygen species, membrane

\footnotetext{
* Corresponding author: Bruno A. M. Carciofi - E-mail: bruno.carciofi@ufsc.br
} 
disruption due to the accumulation of $\mathrm{ZnO}-\mathrm{NPs}$ therein, and internalization of nanoparticles followed by the release of antimicrobial ions $\left(\mathrm{Zn}^{+2}\right)$ (Raghunath and Perumal, 2017; Sirelkhatim et al., 2015). In addition to its unique antibacterial properties, $\mathrm{ZnO}$ is classified as a Generally Recognized as Safe (GRAS) compound by the U.S. Food and Drug Administration (FDA, 2016).

ZnO-NPs can be synthesized through various methods by controlling the synthesis conditions, such as sol-gel (Kolekar et al., 2011), hydrothermal ( $\mathrm{Hu}$ and Chen, 2008), co-precipitation (Zhong Matijević, 1996) and solochemical (Vaezi, 2008) methods. The solochemical process produces nanostructures of $\mathrm{ZnO}$ through the reaction between a precursor solution containing zinc and an alkaline solution. This method has significant advantages, such as synthesis under low temperatures, no addition of a stabilizing agent, short reaction time, low cost, and nanoparticles with controlled morphology and size (Gusatti et al., 2010). The synthesis method directly influences the morphology and size of NPs. In turn, functional activities (chemical, catalytic and biological) of NPs are significantly affected by the combination of their size, morphology, surface area, electronic states and surface charge (Jones et al., 2008; Pasquet et al., 2014; Ramani et al., 2014). Therefore, the synthesis method must be selected to produce NPs with optimum functional activities for the desired application (Fan and Lu, 2005; Gusatti et al., 2010; Sirelkhatim et al., 2015).

Controlling the growth of pathogenic microorganisms is of foremost importance for food safety and public health. Among others, some foodborne pathogenic bacteria have been receiving particular attention in the last decades. Pseudomonas aeruginosa is an ubiquitous environmental bacterial that is the major cause of opportunistic human infections. It is a common soil and water bacteria, widely distributed among fresh foods (Jay et al., 2005; Stover et al., 2000). Bacillus cereus is a pathogenic bacterium commonly isolated from soil and easily spread in the environment (Granum and Lindbäck, 2013). Humans are the primary reservoir of $S$. aureus, and food contaminated during its preparation is the most significant source of staphylococcal food poisoning (Seo and Bohach, 2013). Salmonella spp. is a resilient bacterium capable of adapting to temperature, $\mathrm{pH}$, and water activity beyond their normal growth range, posing high risks to safety (Li et al., 2013).

The present study aimed to characterize $\mathrm{ZnO}$ NPs synthesized via a solochemical technique and to evaluate their antibacterial activity against the above mentioned foodborne Gram-positive and Gramnegative pathogenic bacteria: $S$. aureus, $B$. cereus, $S$. Typhimurium and $P$. aeruginosa, and to obtain both minimum bactericidal and inhibitory concentrations for each of them by a proposed broth dilution method.

\section{MATERIAL AND METHODS}

\section{ZnO-NPs}

$\mathrm{ZnO}-\mathrm{NPs}$ were synthesized the by the solochemical method as described by Gusatti et al. (2010) and kindly provided by Kher Nanotecnologia Química Ltda. (Santa Catarina, Brazil). Immediately before each test, $\mathrm{ZnO}-\mathrm{NPs}$ suspensions in different concentrations were prepared by dispersing the ZnO-NPs in Milli-Q water using an ultrasonic bath (1650A, Unique) for $30 \mathrm{~min}$ followed by vortex mixing (AP56, Phoenix) for $5 \mathrm{~s}$.

\section{Characterization of $\mathrm{ZnO}$-NPs}

ZnO-NPs were characterized by transmission electron micrographs (TEM) (JEM-1011 TEM, $100 \mathrm{kV}$ ) and X-ray diffraction (XRD) (X'Pert, Philips, The Netherlands). TEM analyses used an aqueous $\mathrm{ZnO}-\mathrm{NPs}$ dispersion with $1.0 \mathrm{mg} \mathrm{mL}^{-1}$ placed on a grid and kept at room temperature until complete solvent evaporation. A TEM image with 200 whole $\mathrm{ZnO}-\mathrm{NPs}$ was used to estimate the particle's length and diameter with the help of specific software (ImageJ1.48v, Wayne Rasband, USA) for digital measurements. XRD analyses were done at $40 \mathrm{kV}$ and $30 \mathrm{~mA}$ with $\mathrm{CuK}$ at $1.5406 \AA$ wavelengths. The samples were analyzed in an interval of $2 \theta$ between $20^{\circ}$ and $80^{\circ}$ with increments of $0.05^{\circ} \mathrm{s}$.

\section{Antibacterial activity}

The antibacterial activity of $\mathrm{ZnO}-\mathrm{NPs}$ was tested against Gram-positive bacteria, Bacillus cereus (ATCC 11778) and Staphylococcus aureus (ATCC 25923), and Gram-negative bacteria, Pseudomonas aeruginosa (ATCC 27853) and Salmonella Typhimurium (ATCC 1428). Stock cultures were prepared by inoculating the strains in Tryptone Soya Agar (TSA) (Himedia, India), followed by incubation at $35^{\circ} \mathrm{C}$ for $24 \mathrm{~h}$. These cultures were kept at $4{ }^{\circ} \mathrm{C}$ until the preparation of the working cultures. Working cultures were obtained by transferring a loopful from the stock culture into $5 \mathrm{~mL}$ of Brain Heart Infusion broth (BHI) (Oxoid, England) and incubating at $35^{\circ} \mathrm{C}$ for $24 \mathrm{~h}$.

\section{Diffusion methods}

Disk diffusion and agar well diffusion methods were accomplished aiming at a qualitative screening for bacteria susceptibility and to select the ZnO-NPs concentration for the broth dilution method. Disc diffusion tests started by swabbing the working cultures on the agar surface. Then, sterile discs of filter paper ( 9 mm diameter) were impregnated with $10 \mu \mathrm{L}$ of sterile $\mathrm{ZnO}-\mathrm{NPs}$ suspensions and placed onto the inoculated agar surface. For the well diffusion, the working cultures were pour plated. After the agar solidification, wells (5 mm diameter) were aseptically made and filled with $32 \mu \mathrm{L}$ of sterile $\mathrm{ZnO}$-NPs suspensions. 
For both methods, Müeller-Hinton Agar (Kasvi, Italy) was used. Initial cell concentration was around $10^{9}$ $\mathrm{CFU} \mathrm{mL}^{-1}$, and aqueous $\mathrm{ZnO}-\mathrm{NPs}$ suspensions ranged between 0.01 and $100 \mathrm{mg} \mathrm{mL}^{-1}$. Positive and negative control tests were ciprofloxacin $\left(0.02 \mathrm{mg} \mathrm{mL}^{-1}\right)$ and Milli-Q water, respectively. After incubation at $35^{\circ} \mathrm{C}$ for $48 \mathrm{~h}$, the presence or absence of inhibition zones around the discs and wells were observed.

\section{Broth dilution}

Quantitative tests were performed in tubes with Nutrient Broth (NB) (Acumedia, USA) $(5 \mathrm{~mL})$ and $\mathrm{ZnO}-\mathrm{NPs}$ at final concentrations of $0.05,0.5,1.0$, and $2.0 \mathrm{mg} \mathrm{mL}^{-1}$. Positive and negative control tests were ciprofloxacin $\left(0.02 \mathrm{mg} \mathrm{mL}^{-1}\right)$ and Milli-Q water, respectively. The test tubes were inoculated with the working culture to reach an initial cell concentration around to $10^{5} \mathrm{CFU} \mathrm{mL} \mathrm{mL}^{-1}$ and then incubated under shaking conditions (TECNAL, TE820, Brazil) at $35^{\circ} \mathrm{C}$. After 0,24 and $48 \mathrm{~h}$ of incubation, cell concentration was determined by serial dilution in peptone water $(0.1 \%)$ followed by spread plating in Plate Count Agar (PCA) (Kasvi, Italy). Plates were incubated at $35{ }^{\circ} \mathrm{C}$ for $24 \mathrm{~h}$. The Minimum Bactericidal Concentration (MBC) was defined as the lowest concentration at which no bacterial colonies were detected in the $10^{-1}$ dilution after $48 \mathrm{~h}$ incubation, while the Minimum Inhibitory Concentration (MIC) was the concentration at which the bacterial concentration after $48 \mathrm{~h}$ incubation was equal to the initial cell concentration.

\section{Microbial growth curve}

The bacterial growth curve of each strain was determined in media containing the respective MIC and $\mathrm{MBC}$ of $\mathrm{ZnO}-\mathrm{NPs}$ suspensions. Sterile bottles with $50 \mathrm{~mL}$ of NB were inoculated with a loopful of the working culture and incubated at $35^{\circ} \mathrm{C}$ for $1.5 \mathrm{~h}$ to reach an initial cell concentration of $10^{5} \mathrm{CFU} \mathrm{mL}^{-1}$. Then, $\mathrm{ZnO}-\mathrm{NPs}$ dispersions were added to the bottles at levels equal to the MIC and MBC of each bacterial strain. Positive and negative control tests were ciprofloxacin $\left(0.02 \mathrm{mg} \mathrm{mL}^{-1}\right)$ and Milli-Q water, respectively. The bottles were incubated under agitation at $35^{\circ} \mathrm{C}$. After pre-determined incubation periods, cell concentration was determined by serial dilution in peptone water $(0.1 \%)$, followed by spread plating in Plate Count Agar (PCA) (Kasvi, Italy) and incubation at $35^{\circ} \mathrm{C}$ for $24 \mathrm{~h}$.

\section{RESULTS}

\section{ZnO-NPs characterization}

XRD diffraction results (Figure 1) demonstrated a pattern that matched with the standard of $\mathrm{ZnO}$ provided by the Joint Committee on Powder Diffraction Standards (JCPDS). This result showed the hexagonal

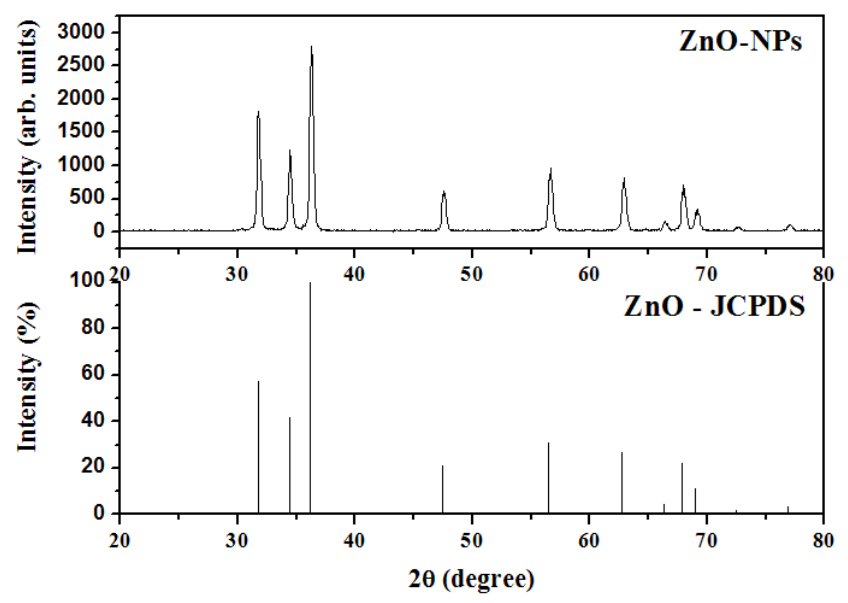

Figure 1. XRD patterns of present $\mathrm{ZnO}-\mathrm{NPs}$ (top) and for standard $\mathrm{ZnO}$ (bottom) provided by Joint Committee on Powder Diffraction Standards (JCPDS), International Centre for Diffraction Data, card number 01-089-1397.

wurtzite structure of the studied $\mathrm{ZnO}-\mathrm{NPs}$, with spatial group $\mathrm{P}_{3} m c$ and network parameters $\mathrm{a}=3.25 \AA$ and $\mathrm{c}=5.21$, as specified in the card number. The nanoparticles showed a high purity level, as no peaks of any other phase were detected.

$\mathrm{ZnO}$-NPs were predominantly rod-like shaped as depicted by the TEM image (Figure 2a), with varying

(a)

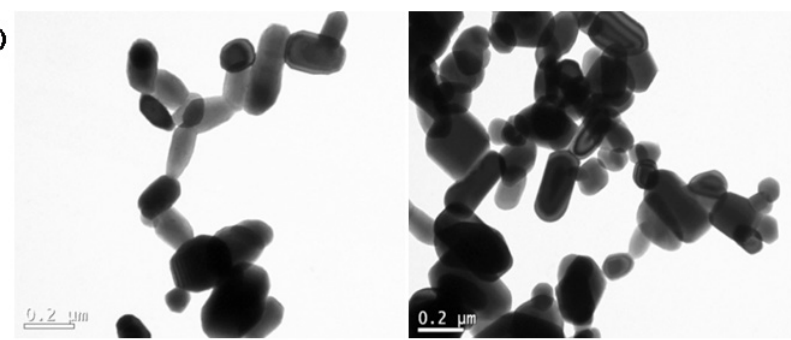

(b)

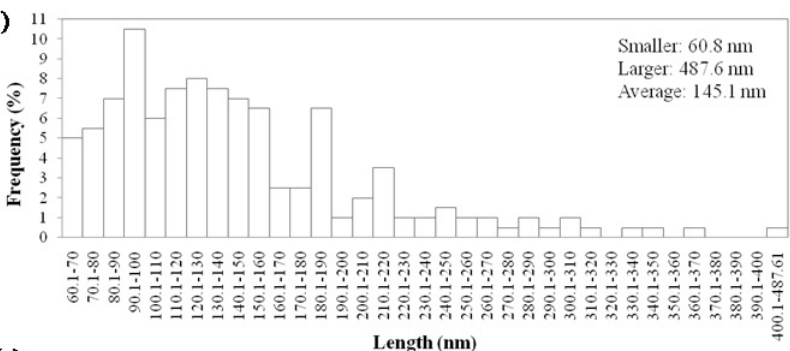

(c) Length (nm)

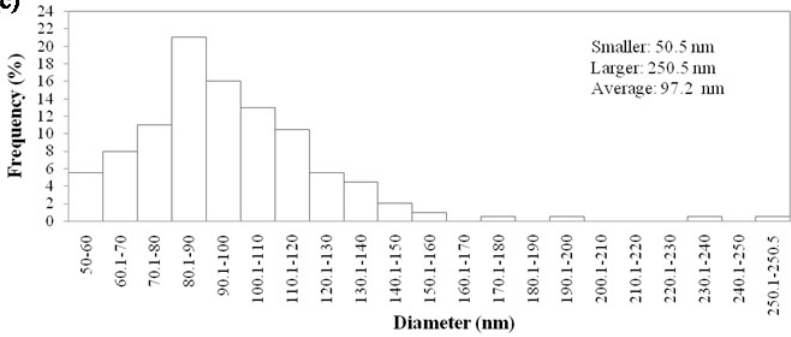

Figure 2. Characterization of the ZnO-NPs: (a) TEM images and frequency distribution histograms of the (b) length and (c) diameter. 
length and diameter according to the frequency distribution histograms (Figures $2 \mathrm{~b}$ and 2c). The nanoparticle average length and diameter were 145.1 and $97.2 \mathrm{~nm}$, respectively. The histograms show that, for the established ranges, the nanoparticles were higher from 90.1 to $100 \mathrm{~nm}$ in length $(10.5 \%$ frequency) and between 80.1 and $90 \mathrm{~nm}$ in diameter (21\% frequency).

\section{Antibacterial activity}

\section{Diffusion in agar}

For $S$. aureus, the inhibition halo was present in concentrations equal to and higher than 0.1 and $2.5 \mathrm{mg}$ $\mathrm{mL}^{-1}$ for the disk and the agar well diffusion methods, respectively. For $S$. Typhimurium, the inhibition halo was present in concentrations equal to and higher than $2.5 \mathrm{mg} \mathrm{mL}^{-1}$ for both methods. For P. aeruginosa, the inhibition halo was observed in concentrations equal to and higher than $1 \mathrm{mg} \mathrm{mL}^{-1}$ for the disk diffusion, and no evident inhibition was found in the agar well method, for which only some spots with an absence of growth were observed in concentrations equal to and higher than $0.1 \mathrm{mg} \mathrm{mL}^{-1}$. For $B$. cereus, no inhibition zone was observed, even for the highest tested concentration of $100 \mathrm{mg} \mathrm{mL}^{-1}$. This result suggests that either $\mathrm{ZnO}$-NPs had no antibacterial effect against this bacterium or these methods are not suitable to detect the antibacterial effect of $\mathrm{ZnO}-\mathrm{NPs}$ against $B$. cereus. The following analyses in broth media did not include tests for $B$. cereus. For all strains, negative controls showed no antibacterial effect, while positive controls had a clear inhibition zone.

\section{Broth dilution}

$\mathrm{ZnO}-\mathrm{NPs} \mathrm{MIC}$ was equal to $0.05 \mathrm{mg} \mathrm{mL}^{-1}(0.6$ $\mathrm{mM}$ ) for $S$. aureus (Table 1). A minor bactericidal effect was observed at the same concentration for $S$. Typhimurium. Despite this effect, $0.05 \mathrm{mg} \mathrm{mL}^{-1}$ was considered as the MIC for $S$. Typhimurium since lower $\mathrm{ZnO}-\mathrm{NPs}$ concentrations were not tested. The MBC for both $S$. Typhimurium and $S$. aureus was equal to $0.5 \mathrm{mg} \mathrm{mL}^{-1}(6.1 \mathrm{mM})$ as no viable cells were detected after $48 \mathrm{~h}$.

Table 1. $\log (N) / \log \left(N_{0}\right)^{*}$ for broth dilution tests at different $\mathrm{ZnO}-\mathrm{NPs}$ concentrations after $48 \mathrm{~h}$ incubation at $35^{\circ} \mathrm{C}$. Positive control and negative controls were ciprofloxacin (0.02 $\left.\mathrm{mg} \mathrm{mL}^{-1}\right)$ and Milli-Q water, respectively.

\begin{tabular}{|c|c|c|c|c|c|c|}
\hline & \multicolumn{4}{|c|}{ ZnO-NPs (mg mL $\left.\mathrm{m}^{-1}\right)$} & \multirow{2}{*}{$\begin{array}{l}\text { Positive } \\
\text { control }\end{array}$} & \multirow{2}{*}{$\begin{array}{c}\text { Negative } \\
\text { control }\end{array}$} \\
\hline & 0.05 & 0.5 & 1.0 & 2.0 & & \\
\hline S. aureus & 1.0 & 0.0 & ${ }^{* * *}$ & $*^{* *}$ & 0.0 & 1.8 \\
\hline$S$. Typhimurium & 0.83 & 0.0 & $* *$ & $* *$ & 0.0 & 2.0 \\
\hline P. aeruginosa & $* *$ & 1.6 & 1.6 & 1.7 & 0.0 & 1.7 \\
\hline
\end{tabular}

$* N_{0}$ is the initial cell concentration $(\mathrm{CFU} / \mathrm{mL})$, and $N$ is the cell concentration after $48 \mathrm{~h}$ incubation.

**Concentrations not tested.
$P$. aeruginosa growth was not affected by the maximum tested concentration of $2 \mathrm{mg} \mathrm{mL}^{-1}$ (24.6 $\mathrm{mM}$ ), and the bacterial concentration increased similarly to the negative control for all tested $\mathrm{ZnO}-$ NPs concentrations. Concentrations higher than $2 \mathrm{mg}$ $\mathrm{mL}^{-1}$ were not tested as much $\mathrm{ZnO}$ precipitation was observed, hampering the results.

\section{Microbial growth curve}

After 24h, no viable cells of $S$. aureus (Figure 3) and $S$. Typhimurium (Figure 4) were detected when at $\mathrm{MBC}$, while the negative control reached the maximum

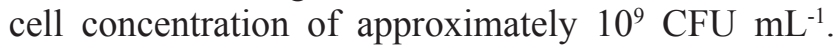
After $6 \mathrm{~h}$ of incubation, $\mathrm{ZnO}-\mathrm{NPs}$ at $\mathrm{MBC}$ reduced bacterial count in 38 and $61 \%$ when comparing to the negative control for $S$. aureus and $S$. Typhimurium, respectively. It indicates that $\mathrm{ZnO}-\mathrm{NPs}$ can be more effective against $S$. Typhimurium compared to $S$. aureus. The growth curves at MIC presented a decrease in the cell concentration in the first $24 \mathrm{~h}$, followed by

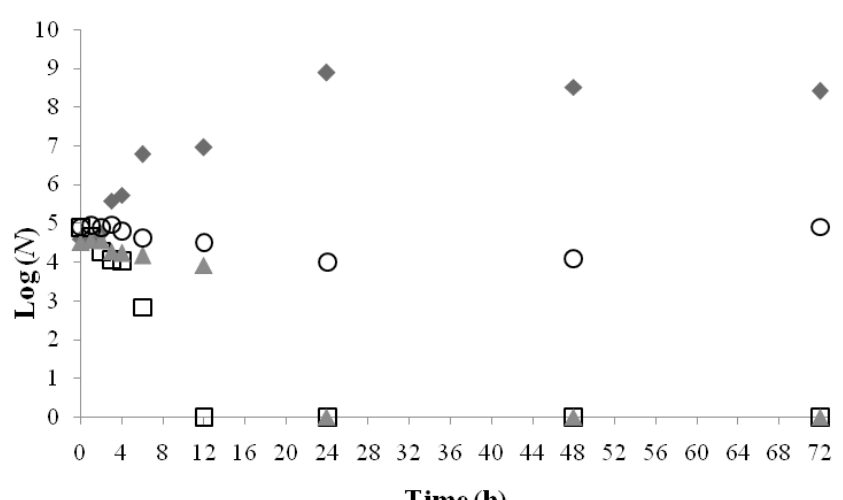

Figure 3. $S$. aureus cell concentration $[\log (N)]$ over time for (o) ZnO-NPs MIC (0.05 $\left.\mathrm{mg} \mathrm{mL}^{-1}\right)$, ( $\left.\mathbf{A}\right) \mathrm{ZnO}$ NPs MBC (0.5 $\left.\mathrm{mg} \mathrm{mL}^{-1}\right),(\diamond)$ negative control (Milli-Q water) and ( $\square$ ) positive control (ciprofloxacin, $0.02 \mathrm{mg}$ $\left.\mathrm{mL}^{-1}\right) . N$ is the cell concentration in $\mathrm{CFU} \mathrm{mL} \mathrm{mL}^{-1}$.

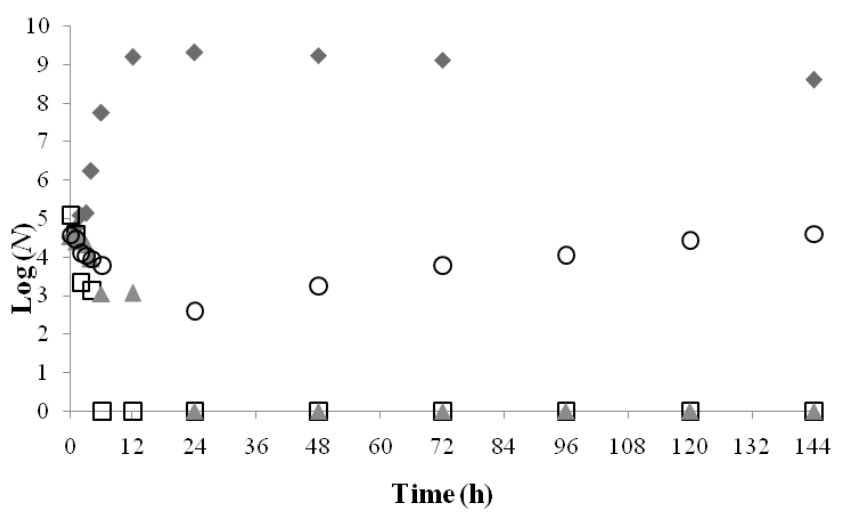

Figure 4. $S$. Typhimurium cell concentration $[\log (N)]$ over time for (०) ZnO-NPs MIC (0.05 $\left.\mathrm{mg} \mathrm{mL}^{-1}\right)$, ( $\left.\mathbf{\Delta}\right)$

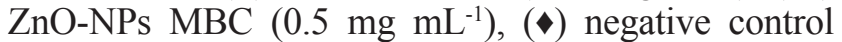
(Milli-Q water) and ( $\square$ ) positive control (ciprofloxacin, $0.02 \mathrm{mg} \mathrm{mL}^{-1}$ ). $N$ is the cell concentration in $\mathrm{CFU} \mathrm{mL}^{-1}$. 
an increase, reaching concentrations close to the initial cell concentration for both microorganisms. This decrease in cell concentration was also observed for $S$. Typhimurium during the MIC estimation (Table 1).

$P$. aeruginosa growth was not inhibited in $\mathrm{ZnO}-$ NPs concentrations up to $2 \mathrm{mg} \mathrm{mL}^{-1}$ (Figure 5). A minor effect of the ZnO-NPs can be observed at $48 \mathrm{~h}$ as bacterial cell concentrations were lower than the negative control for all time points. After 216 $\mathrm{h}$, the cultures containing $\mathrm{ZnO}-\mathrm{NPs}$ reached a cell concentration approximately 3 logs higher than the initial concentration, while the negative control was about 3.8 times higher.

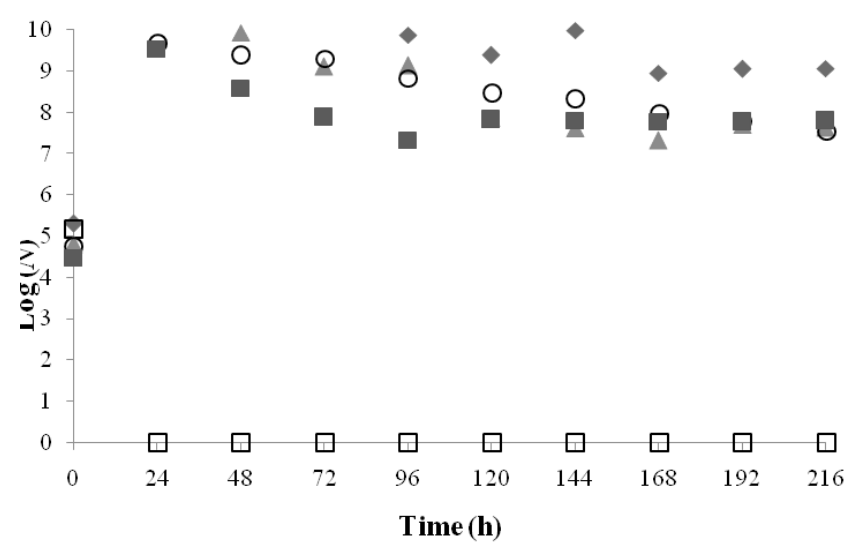

Figure 5. $P$. aeruginosa cell concentration $[\log (N)]$ over time for $\mathrm{ZnO}-\mathrm{NPs}$ at ( $\mathbf{\Delta}) 0.5 \mathrm{mg} \mathrm{mL}^{-1}$ (०) $1.0 \mathrm{mg}$ $\mathrm{mL}^{-1}$ and (घ) $2.0 \mathrm{mg} \mathrm{mL}^{-1}$, (») negative control (Milli-Q water) and ( $\square$ ) positive control (ciprofloxacin, $0.02 \mathrm{mg}$ $\left.\mathrm{mL}^{-1}\right) . N$ is the cell concentration in CFU $\mathrm{mL}^{-1}$.

\section{DISCUSSION}

Agar diffusion tests were performed as a qualitative test to observe and predict the $\mathrm{ZnO}$-NPs antibacterial behavior. These methods have many advantages over other methods, such as simplicity, low cost, the ability to test a high number of microorganisms and antimicrobial agents. However, it is not able to determine the $\mathrm{MIC}$ or $\mathrm{MBC}$, as it is impossible to determine the diffusion of the antimicrobial agent in the agar (Balouiri et al., 2016). The broth media assay can be considered as confirmative and more accurate than the agar diffusion assay as the chances of nanoparticle-bacteria interactions are higher in the liquid phase (Negi et al., 2012). It is essential for $\mathrm{ZnO}$ particles to contact or penetrate into microbial cells to express the antibacterial activity (Mirhosseini and Firouzabadi, 2013). Therefore, MIC and MBC values were accurately estimated by the broth dilution methods, which were equal to $0.05 \mathrm{mg} \mathrm{mL}^{-1}(0.6$ $\mathrm{mM})$ and $0.5 \mathrm{mg} \mathrm{mL}^{-1}(6.1 \mathrm{mM})$ for both $S$. aureus and $S$. Typhimurium, respectively, while no significant bactericidal effect was observed for $P$. aeruginosa in concentrations up to $2 \mathrm{mg} \mathrm{mL}^{-1}$ (24.6 mM) (Table 1).
Agar diffusion tests revealed that $B$. cereus was highly resistant to $\mathrm{ZnO}-\mathrm{NPs}$, the reason why broth media tests were not done for this bacterium.

Many studies have reported that $\mathrm{ZnO}-\mathrm{NPs}$ antimicrobial activity is significantly affected by different particle morphologies (Stanković et al., 2013; Talebian et al., 2013). This shape-dependent activity can be explained regarding the percent of active facets on the NPs. Thus, NPs research has been motivated to achieve selective nanostructured $\mathrm{ZnO}$ for antibacterial tests (Sirelkhatim et al., 2015). Particle size and concentration also have an essential influence on the antimicrobial activity. Studies have revealed that the smaller the NP size, the higher their toxic effect on microorganisms (Nair et al., 2009; Yamamoto, 2001). Smaller nanoparticles have relatively large interfacial area and can easily penetrate bacterial membranes, increasing their antibacterial effectiveness (Ramani et al., 2014). The $\mathrm{ZnO}$-NPs used in the present work were synthesized by the solochemical process and presented a nanorod shape with a wurtzite crystalline structure with average length and diameter of 145.1 and 97.2 $\mathrm{nm}$, respectively.

The results of the antibacterial effect of the ZnO-NPs synthesized via the solochemical method evaluated in the present study indicate that the MIC and $\mathrm{MBC}$ were smaller than the values from previous studies with ZnO-NPs synthesized by different methods, even for smaller particle sizes, or evaluated by other methodologies. For instance, $\mathrm{ZnO}-\mathrm{NPs}$ with an average size of $50 \mathrm{~nm}$ had MIC values for $P$. aeruginosa, $S$. Typhimurium and $S$. aureus of 26, 22, and $10 \mathrm{mM}$, respectively (Tayel et al., 2011), which are much bigger than the values observed in the present work. A comparative scheme is presented in Table 2, showing literature results for the MIC and $\mathrm{MBC}$ of $\mathrm{ZnO}$ obtained from different methods against Salmonella and $S$. aureus.

$\mathrm{ZnO}-\mathrm{NPs}$ did not affect the growth of $P$. aeruginosa in the range evaluated in the present study. This result corroborates Jan et al. (2013), who observed an antibacterial effect of $\mathrm{ZnO}-\mathrm{NPs}$ more effective against $S$. aureus than $P$. aeruginosa. Lee et al. (2014) found that $\mathrm{ZnO}-\mathrm{NPs}(<50 \mathrm{~nm})$ at $10 \mathrm{mM}$ only slightly decrease the growth of $P$. aeruginosa planktonic cells, while successfully inhibiting biofilm formation. These authors suggested a MIC of about $300 \mathrm{mM}$ against the planktonic cells.

A remarkable result was observed by following bacterial growth up to 9 days when the MIC concentration was applied to $S$. aureus (Figure 3) and $S$. Typhimurium (Figure 4). In both, an initial decrease was observed followed by the latest increase of the microbial population under this non-lethal condition. Initially, a population sensitive to $\mathrm{ZnO}-\mathrm{NPs}$ dies, consequently decreasing the total concentration. Then, a resistant population can persist for a long time or even 
Table 2. Literature results for $S$. Typhimurium and S. aureus inhibition, and MIC and MBC values of aqueous $\mathrm{ZnO}-$ NPs suspensions.

\begin{tabular}{|c|c|c|c|c|}
\hline $\begin{array}{l}\text { Method of synthesis } \\
\text { (reference) }\end{array}$ & Size & Bacteria evaluated and observations & MIC & МBC \\
\hline $\begin{array}{l}\text { Solochemical } \\
\text { (Present work) }\end{array}$ & $97 \mathrm{~nm}$ & $\begin{array}{l}\text { Great inhibition effect against } S \text {. Typhimurium and } \\
\text { S. aureus }\end{array}$ & $\begin{array}{l}0.05 \mathrm{mg} / \mathrm{mL} \\
(0.6 \mathrm{mM})\end{array}$ & $\begin{array}{l}0.5 \mathrm{mg} / \mathrm{mL} \\
(6.1 \mathrm{mM})\end{array}$ \\
\hline $\begin{array}{l}\text { Commercial sample from } \\
\text { Sigma-Aldrich, USA } \\
\text { (Tayel et al., 2011) }\end{array}$ & $50 \mathrm{~nm}$ & $\begin{array}{l}\text { Inhibition effect against } S \text {. Typhimurium and } S \text {. } \\
\text { aureus }\end{array}$ & $\begin{array}{l}22 \text { and } \\
10 \mathrm{mM} \text {, } \\
\text { respectively }\end{array}$ & ( \\
\hline Commercial sample from & & & & \\
\hline $\begin{array}{l}\text { Teconan, Spain. } \\
\text { (Mirhosseini and Firouzabadi, } \\
\text { 2013) }\end{array}$ & $20 \mathrm{~nm}$ & $\begin{array}{l}2 \mathrm{mM} \text { do not inhibit the growth of } S . \text { aureus after } \\
24 \mathrm{~h}(5 \mathrm{mM} \text { showed } 33.9 \% \text { of growth reduction) }\end{array}$ & Not found & $10 \mathrm{mM}$ \\
\hline Commercial sample from & $8 \mathrm{~nm}$ and & $0.5 \mathrm{mM}(8 \mathrm{~nm})$ do not inhibit the S. aureus growth. & $1 \mathrm{mM}$ & - \\
\hline $\begin{array}{l}\text { Sigma-Alaricn, USA } \\
\text { (Jones et al., 2008) }\end{array}$ & $50-70 \mathrm{~nm}$ & $\begin{array}{l}5 \mathrm{mM}(50-/ 0 \mathrm{~nm}) \text { presented } 40-50 \% \text { of growth } \\
\text { inhibition. }\end{array}$ & & \\
\hline Commercial sample from & & Inhibition effect against Salmonella enterica & & \\
\hline $\begin{array}{l}\text { Inframat Advanced Materials } \\
\text { LLC, USA. } \\
\text { (Xie et al., 2011) }\end{array}$ & $30 \mathrm{~nm}$ & $\begin{array}{l}\text { serovar Enteritidis } \\
10 \mathrm{mg} / \mathrm{ml} \text { led to } 1-\text { or } 2-\log \text { reduction in viable cells } \\
\text { after an } 8 \mathrm{~h} \text { exposure. }\end{array}$ & $0.4 \mathrm{mg} / \mathrm{mL}$ & - \\
\hline $\begin{array}{l}\text { Nosaka method(Emami- } \\
\text { Karvani and Chehrazi, 2011) }\end{array}$ & $3 \mathrm{~nm}$ & Inhibition effect against $S$. aureus & $0.5 \mathrm{mg} / \mathrm{mL}$ & $8 \mathrm{mg} / \mathrm{mL}$ \\
\hline $\begin{array}{l}\text { Kawano method } \\
\text { (Ramani et al., 2013) }\end{array}$ & $78 \mathrm{~nm}$ & $\begin{array}{l}0.045 \mathrm{mg} / \mathrm{mL} \text { partial growth inhibition effect } \\
\text { against } S . \text { aureus and Salmonella typhimurium. }\end{array}$ & - & - \\
\hline $\begin{array}{l}\text { Solochemical } \\
\text { (Sornalatha et al., 2015) }\end{array}$ & $37 \mathrm{~nm}$ & $\begin{array}{l}\text { Presented antimicrobial index of } 40 \% \text { to } 05 \\
\mathrm{mg} / \mathrm{mL}, 50 \% \text { to } 0.750 \mathrm{mg} / \mathrm{mL} \text { and } 66 \% \text { to } 1.000 \\
\mathrm{mg} / \mathrm{mL} \text { against } S \text {. aureus. }\end{array}$ & - & - \\
\hline $\begin{array}{l}\text { Commercial from Sigma, } \\
\text { Australia. } \\
\text { (Duffy et al., 2018) }\end{array}$ & $<50 \mathrm{~nm}$ & Inhibition effect against Salmonella Typhimurium & $0.313 \mathrm{mg} / \mathrm{mL}$ & $>5 \mathrm{mg} / \mathrm{mL}$ \\
\hline $\begin{array}{l}\text { Solvothermal synthesis } \\
\text { (Raghupathi, Koodali and } \\
\text { Manna, 2011) }\end{array}$ & $12 \mathrm{~nm}$ & $\begin{array}{l}\text { Salmonella Typhimurium growth was inhibited by } \\
\text { about } 50 \% \text { with } 10 \mathrm{mM} \text {. }\end{array}$ & - & - \\
\hline
\end{tabular}

start to grow. This behavior occurs due to phenotypic heterogeneity in the microbial population, resulting in distinct subpopulations. Microbial populations benefit from the creation of variant subpopulations that have the potential to be better prepared to persist during stress conditions (Avery, 2006), such as the presence of $\mathrm{ZnO}$. This bacterial behavior reveals the time dependency of the MIC methodology; experiments with longer incubation times will most probably result in different MIC results. This fact, among many others, should be taken into account when designing products containing new antimicrobial compounds.

\section{CONCLUSIONS}

ZnO-NPs obtained by the solochemical method showed a strong antimicrobial effect against both Gramnegative $S$. aureus and $S$. Typhimurium. On the other hand, the effect was minor against $P$. aeruginosa for the tested concentrations, whereas no apparent effect was observed for $B$. cereus. The antibacterial activity observed was superior to nanoparticles obtained by other processes, even when the latter presented smaller particle sizes. It can result from both nanoparticle properties and the evaluation methodology. From any of them, the result impacts the amount of required $\mathrm{ZnO}-\mathrm{NPs}$, showing potential cost savings for reaching similar antibacterial effect. Importantly, the solochemical process has many advantages over other methods of nanoparticle synthesis, such as low cost and synthesis under low temperatures. The growth and survival curves obtained in this study enhance our understating of the $\mathrm{ZnO}$-NPs antibacterial action over time, often neglected in the literature. Finally, the results obtained in this study suggest that the use of $\mathrm{ZnO}-\mathrm{NPs}$ as an antibacterial agent in food systems can successfully inhibit some of the most dangerous and frequent foodborne pathogens.

\section{ACKNOWLEDGMENTS}

The authors are thankful for the financial support from the Brazilian governmental agencies: National Council for Scientific and Technological Development (CNPq), Foundation to Support Research and Innovation in Santa Catarina State (FAPESC), and Coordination for the Improvement of Higher Education Personnel (CAPES). The authors also thank the laboratories Central de Análises and Laboratório Central de Microscopia Eletrônica (LCME) from the Federal University of Santa Catarina for the technical support with characterization analyses. 


\section{REFERENCES}

Ann, L. C., Mahmud, S., Bakhori, S. K. M., Sirelkhatim, A., Mohamad, D., Hasan, H., Rahman, R. A., Antibacterial responses of zinc oxide structures against Staphylococcus aureus, Pseudomonas aeruginosa and Streptococcus pyogenes, Ceramics International, 40, 2993-3001 (2014). https://doi. org/10.1016/j.ceramint.2013.10.008

Avery, S. V., Microbial cell individuality and the underlying sources of heterogeneity. Nature Reviews. Microbiology, 4, 577-587 (2006). https:// doi.org/10.1038/nrmicro1460

Azeredo, H. M. C., Antimicrobial nanostructures in food packaging. Trends in Food Science and Technology, 30, 56-69 (2013). https://doi. org/10.1016/j.tifs.2012.11.006

Balouiri, M., Sadiki, M., Ibnsouda, S. K., Methods for in vitro evaluating antimicrobial activity: A review. Journal of Pharmaceutical Analysis, 6, 71-79 (2016). https://doi.org/10.1016/j.jpha.2015.11.005

Duffy, L. L., Osmond-McLeod, M. J., Judy, J., King, $\mathrm{T}$., Investigation into the antibacterial activity of silver, zinc oxide and copper oxide nanoparticles against poultry-relevant isolates of Salmonella and Campylobacter. Food Control, 92, 293-300 (2018). https://doi.org/10.1016/j.foodcont.2018.05.008

Emami-Karvani, Z., Chehrazi, P., Antibacterial activity of $\mathrm{ZnO}$ nanoparticle on gram-positive and gramnegative bacteria. African Journal Microbiology Research, 5, 1368-1373 (2011). https://doi. org/10.5897/AJMR10.159

Fan, Z., Lu, J. G., Zinc Oxide Nanostructures: Synthesis and Properties. Journal of Nanoscience and Nanotechnology, 5, 1-13 (2005). https://doi. org/10.1166/jnn.2005.182

FDA (Food and Drug Administration), Electronic Code of Federal Regulations. Title 21, Chapter I, Subchapter E, Part 582, Subpart F, §582.5991 (2016). Last seen: October 10, 2016, from http:// www.ecfr.gov/cgi-bin/text-idx?SID=a55fc716d5af c41 aaa9434cddd5e $5 \mathrm{f} 57 \mathrm{mc}=$ truenode $=\mathrm{se} 21.6 .582$ 15991 rgn $=\operatorname{div} 8$

Granum, P. E., Lindbäck, T., Bacillus cereus. In M. P. Doyle R. L. Buchanan (Eds.), Food Microbiology: Fundamentals and Frontiers. 4th ed., p. 491-502, ASM Press, Washington, D.C (2013).

Gusatti, M., Rosário, J. A., Campos, C. E. M., Kuhnen, N. C., Carvalho, E. U., Riella, H. G., Bernardin, A. M., Production and Characterization of $\mathrm{ZnO}$ Nanocrystals Obtained by Solochemical Processing at Different Temperatures. Journal of Nanoscience and Nanotechnology, 10, 4348-4351 (2010). https:// doi.org/10.1166/jnn.2010.2198

Han, J. H., Antimicrobial food packaging. In R. Ahvenainen (Ed.), Novel Food Packaging
Techniques, p. 50-70, CRCPress, Boca Raton(2005). https://doi.org/10.1533/9781855737020.1.50

$\mathrm{Hu}, \mathrm{Y}$., Chen, H.-J., Preparation and characterization of nanocrystalline $\mathrm{ZnO}$ particles from a hydrothermal process. Journal of Nanoparticle Research, 10, 401-407 (2008). https://doi.org/10.1007/s11051007-9264-0

Jan, T., Iqbal, J., Ismail, M., Zakaullah, M., Haider Naqvi, S., Badshah, N., Sn doping induced enhancement in the activity of $\mathrm{ZnO}$ nanostructures against antibiotic resistant $S$. aureus bacteria. International Journal of Nanomedicine, 8, 36793687 (2013). https://doi.org/10.2147/IJN.S45439

Jay, J. M., Loessner, M. J., Golden, D. A. Modern Food Microbiology, 7a ed. New York: Springer. (2005).

Jones, N., Ray, B., Ranjit, K. T., Manna, A. C. (2008). Antibacterial activity of $\mathrm{ZnO}$ nanoparticle suspensions on a broad spectrum of microorganisms. FEMS Microbiology Letters, 279, 71-76 (2008). https://doi.org/10.1111/j.1574-6968.2007.01012.x

Kolekar, T. V, Yadav, H. M., Bandgar, S. S., Raskar, A. C., Rawal, S. G., Mishra, G. M., Synthesis By Sol-Gel Method And Characterization Of $\mathrm{ZnO}$ Nanoparticles. Indian Streams Research Journal, 1, 1-4 (2011).

Lee, J.-H., Kim, Y.-G., Cho, M. H., Lee, J., ZnO nanoparticles inhibit Pseudomonas aeruginosa biofilm formation and virulence factor production. Microbiological Research, 169, 888-896 (2014). https://doi.org/10.1016/j.micres.2014.05.005

Li, H., Wang, H., D’Aoust, J.-Y., Maurer, J. Salmonella Species. In M. P. Doyle R. L. Buchanan (Eds.), Food Microbiology: Fundamentals and Frontiers, 4th ed., p. 225-261, ASM Press Washington, D.C. (2013).

Martinez-Gutierrez, F., Olive, P. L., Banuelos, A., Orrantia, E., Nino, N., Sanchez, E. M., Av-Gay, Y., Synthesis, characterization, and evaluation of antimicrobial and cytotoxic effect of silver and titanium nanoparticles. Nanomedicine: Nanotechnology, Biology, and Medicine, 6, 681-688 (2010). https://doi.org/10.1016/j.nano.2010.02.001

Mattoso, L. H. C., Morais, P. C., Durán, N. Nanotecnologia: introdução, preparação e caracterização de nanomateriais e exemplos de aplicação. Artliber, São Paulo, SP (2006).

Medeiros, G. R., Ferreira, S. R. S., Carciofi, B. A. M., High pressure carbon dioxide for impregnation of clove essential oil in LLDPE films. Innovative Food Science \& Emerging Technologies, 41, 206-215 (2017). https://doi.org/10.1016/j.ifset.2017.03.008

Medeiros, G. R., Guimarães, C., Ferreira, S. R. S., Carciofi, B. A. M., Thermomechanical and transport properties of LLDPE films impregnated with clove essential oil by high-pressure $\mathrm{CO}_{2}$. The Journal of Supercritical Fluids, 139, 8-18 (2018). https://doi.org/10.1016/j.supflu.2018.05.006 
Mirhosseini, M., Firouzabadi, F. B., Antibacterial activity of zinc oxide nanoparticle suspensions on food-borne pathogens. International Journal of Dairy Technology, 66, 291-295 (2013). https://doi. org/10.1111/1471-0307.12015

Nair, S., Sasidharan, A., Divya Rani, V. V., Menon, D., Nair, S., Manzoor, K., Raina, S., Role of size scale of $\mathrm{ZnO}$ nanoparticles and microparticles on toxicity toward bacteria and osteoblast cancer cells. Journal of Materials Science: Materials in Medicine, 20, 235-241 (2009). https://doi.org/10.1007/s10856008-3548-5

Negi, H., Agarwal, T., Zaidi, M. G. H., Goel, R., Comparative antibacterial efficacy of metal oxide nanoparticles against Gram negative bacteria. Annals of Microbiology, 62, 765-772 (2012). https://doi.org/10.1007/s13213-011-0317-3

Pasquet, J., Chevalier, Y., Couval, E., Bouvier, D., Noizet, G., Morlière, C., Bolzinger, M. A., Antimicrobial activity of zinc oxide particles on five micro-organisms of the Challenge Tests related to their physicochemical properties. International Journal of Pharmaceutics, 460, 92-100 (2014). https://doi.org/10.1016/j.ijpharm.2013.10.031

Raghunath, A., Perumal, E., Metal oxide nanoparticles as antimicrobial agents: a promise for the future. International Journal of Antimicrobial Agents, 49, 137-152 (2017). https://doi.org/10.1016/j. ijantimicag.2016.11.011

Raghupathi, K. R., Koodali, R. T., Manna, A. C., Size-dependent bacterial growth inhibition and mechanism of antibacterial activity of zinc oxide nanoparticles. Langmuir, 27, 4020-4028 (2011). https://doi.org/10.1021/1a104825u

Ramani, M., Ponnusamy, S., Muthamizhchelvan, C., Cullen, J., Morphology-directed synthesis of $\mathrm{ZnO}$ nanostructures and their antibacterial activity. Colloids and Surfaces B: Biointerfaces, 105, 24-30 (2013). https://doi.org/10.1016/j.colsurfb.2012.12.056

Ramani, M., Ponnusamy, S., Muthamizhchelvan, C., Marsili, E., Amino acid-mediated synthesis of zinc oxide nanostructures and evaluation of their facetdependent antimicrobial activity. Colloids and Surfaces B: Biointerfaces, 117, 233-239 (2014). https://doi.org/10.1016/j.colsurfb.2014.02.017

Savi, G. D., Bortoluzzi, A. J., Scussel, V. M., Antifungal properties of Zinc-compounds against toxigenic fungi and mycotoxin. International Journal of Food Science and Technology, 48, 1834-1840 (2013). https://doi.org/10.1111/ijfs. 12158

Seo, K. S., Bohach, G. A., Staphylococcus aureus. In M. P. Doyle R. L. Buchanan (Eds.), Food Microbiology: Fundamentals and Frontiers, 4th ed., p. 547-593, ASM Press, Washington, D.C (2013).

Sirelkhatim, A., Mahmud, S., Seeni, A., Kaus, N. H. M., Ann, L. C., Bakhori, S. K. M., Mohamad, D.,
Review on zinc oxide nanoparticles: Antibacterial activity and toxicity mechanism. Nano-Micro Letters, 7, 219-242 (2015). https://doi.org/10.1007/ s40820-015-0040-x

Sornalatha, D. J., Bhuvaneswari S., Murugesan, S., Murugakoothan, P., Solochemical synthesis and characterization of $\mathrm{ZnO}$ nanostructures with different morphologies and their antibacterial activity. Optik, 126, 63-67 (2015). https://doi. org/10.1016/j.ijleo.2014.07.138

Stanković, A., Dimitrijević, S., Uskoković, D., Influence of size scale and morphology on antibacterial properties of $\mathrm{ZnO}$ powders hydrothermally synthesized using different surface stabilizing agents. Colloids and Surfaces B: Biointerfaces, 102, 21-28 (2013). https://doi. org/10.1016/j.colsurfb.2012.07.033

Stover, C.-K., Pham, X.-Q., Erwin, A.-L., Mizoguchi, S.-D., Warrener, P., Hickey, M. J., Olson, M. V., Complete genome sequence of Pseudomonas aeruginosa PAO1, an opportunistic pathogen. Nature, 406, 959-964 (2000). https://doi. org/10.1038/35023079

Talebian, N., Amininezhad, S. M., Doudi, M., Controllable synthesis of $\mathrm{ZnO}$ nanoparticles and their morphology-dependent antibacterial and optical properties. Journal of Photochemistry and Photobiology B: Biology, 120, 66-73 (2013). https://doi.org/10.1016/j.jphotobiol.2013.01.004

Tang, Z. X., Fang, X. J., Zhang, Z. L., Zhou, T., Zhang, X. Y., Shi, L. E., Nanosize $\mathrm{MgO}$ as antibacterial agent: Preparation and characteristics. Brazilian Journal of Chemical Engineering, 29, 775-781 (2012). https://doi.org/10.1590/S010466322012000400009

Tang,Z.X., Lv, B. F., MgO nanoparticles as antibacterial agent: Preparation and activity. Brazilian Journal of Chemical Engineering, 31, 591-601 (2014). https:// doi.org/10.1590/0104-6632.20140313s00002813

Tayel, A. A., El-Tras, W. F., Moussa, S., El-Baz, A. F., Mahrous, H., Salem, M. F., Brimer, L. Antibacterial action of zinc oxide nanoparticles against foodborne pathogens. Journal of Food Safety, 31, 211-218 (2011). https://doi.org/10.1111/ j.1745-4565.2010.00287.x

Vaezi, M. R., Two-step solochemical synthesis of $\mathrm{ZnO} /$ $\mathrm{TiO}_{2}$ nano-composite materials. Journal of Materials Processing Technology, 205, 332-337 (2008). https://doi.org/10.1016/j.jmatprotec.2007.11.122

Vargas-Reus, M. A., Memarzadeh, K., Huang, J., Ren, G. G., Allaker, R. P., Antimicrobial activity of nanoparticulate metal oxides against periimplantitis pathogens. International Journal of Antimicrobial Agents, 40, 135-139 (2012). https:// doi.org/10.1016/j.ijantimicag.2012.04.012 
Wahab, R., Mishra, A., Yun, S. Il, Kim, Y. S., Shin, H. S., Antibacterial activity of $\mathrm{ZnO}$ nanoparticles prepared via non-hydrolytic solution route. Applied Microbiology and Biotechnology, 87, 1917-1925 (2010). https://doi.org/10.1007/s00253-010-2692-2

Xie, Y., He, Y., Irwin, P. L., Jin, T., Shi, X., Antibacterial activity and mechanism of action of zinc oxide nanoparticles against Campylobacter jejuni. Applied and Environmental Microbiology, 77, 2325-2331 (2011). https://doi.org/10.1128/AEM.02149-10
Yamamoto, O., Influence of particle size on the antibacterial activity of zinc oxide. International Journal of Inorganic Materials, 3, 643-646 (2001). https://doi.org/10.1016/S14666049(01)00197-0

Zhong, Q., Matijević, E., Preparation of uniform zinc oxide colloids by controlled double-jet precipitation. Journal of Material Chemistry, 6, 443-447 (1996). https://doi.org/10.1039/jm9960600443 
